\title{
Local governance for local governments: A framework for addressing climate change
}

Commonwealth Journal of Local Governance

Issue 7: November 2010

http:/lepress.lib.uts.edu.au/ojs/index.php/cjlg

\section{Melissa Nursey-Bray ${ }^{1}$}

Geography, Environment and Population

University of Adelaide, South Australia

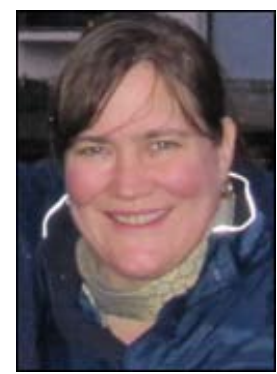

\section{Introduction}

Climate science has established that climate change and associated global warming will impact the world. Already the global temperature has risen by between 0.2 and 0.6 degrees centigrade since the late 19th century, and in Australia, average temperatures have increased by 0.8 degrees centigrade (Pillora 2010). Furthermore, the last IPCC report concluded for the first time not only that climate change was real but reported a 90\% certainty that it was also human induced (IPCC 2007). Moreover, Australia is predicted by 2030 to experience the following: (i) a further $1^{\circ} \mathrm{C}$ of warming; (ii) up to $20 \%$ more months of drought; (iii) up to $25 \%$ increase in days of very high or extreme fire danger; (iv) increases in storm surges and severe weather events; and (v) a rise in mean sea level, with the anticipated range of sea level rise to be between 18 to $76 \mathrm{~cm}$ by 2100 (Pillora 2010: 4; IPCC 2007).

\footnotetext{
${ }^{1}$ I would like to thank all local governments in Tasmania that I worked with and all individuals from the Northern regions. I would also like to thank Scott Schilg and Emma Williams of NRM North, Launceston for offering me the opportunity and funds to conduct the workshops. I would also like to thank Christine Matiera, of the Local Government Association of Tasmania, in her good advice to me throughout this project. Finally, I would like to thank staff at the National Centre for Marine Conservation and Resource Sustainability, Australian Maritime College, UTAS, especially Dr. Troy Gaston, for their support while doing this project.
} 


\section{Implications for Local Government}

Local governments perhaps face the most daunting challenge in relation to climate change as they are the arbiters of day-to-day policy implementation. What then will be some of the implications for local government of these predictions, and why does it matter?

Firstly changes will be felt at both policy and practical levels. For example, planning policy and development assessments will be affected as will decision making about the location of urban expansion areas. Increased uncertainty in land use planning and pressure to respond to these changes from rate payers, as well as the projected increased pressure on resources (i.e. emergency services) are additional concerns (Pillora 2010). The loss of private property and community assets also begs questions about how insurance will be handled into the future. For coastal local governments, erosion, inundation, and subsequent impacts on infrastructure will potentially cost millions and require forward planning. Responding to these challenges will require shifts in how economic development and tourism programs are navigated into the future, as will changes in social mobility, community structure and migration of people in and out of cities (Pillora 2010). Community health issues, bio security risks, water management and environmental management - whether along the coast or bio-diversity protection generally - are all likely to be the planning challenges of the 21st century. These implications also raise the possibility of litigation or claims, a prospect that should motivate further action from local governments concerning climate change.

\section{The Law, Climate Change and Local Government}

Local governments are under intense pressure in relation to liability. Council decisions can theoretically be challenged on the basis that (i) they may contribute to greenhouse gas emissions, i.e. development approvals for power or other polluting activities, or (ii) that they unreasonably fail to take into account the likely effects of climate change when exercising a wide range of their service, planning and development activities. Climate change is an activity that could be used as the basis of testing what is 'reasonably foreseeable' (England 2006). As England notes, types of decisions may include: those questioning the appropriateness of development approvals in flood prone, coastal zone or at risk areas; the adequacy of building standards to withstand extreme weather events which can lead to erosion and landslides; the adequacy of emergency procedures (when put to the test more frequently); failure to undertake disease prevention programmes, 
and; failure to preserve 'public' natural assets in the face of climate change - if and when the technology becomes available (England 2006). Moreover, in relation to negligence, courts could award damages if the following can be shown:

- a reasonable person in the defendant's position could have avoided the damage by exercising reasonable care; and

- the defendant was in such a relationship to the plaintiff that he or she ought to have acted with that degree of reasonable care.

Already, a number of legal precedents have been set in relation to the issue of climate change and local government (Edgar 2010). For example, in 2007 the Land and Environment Court of NSW ruled against a \$250 million housing and aged care development due to the possible impact of coastal flooding caused by climate change. In August 2008, the Victorian Civil and Administrative Tribunal handed down a landmark decision where it quashed a proposal for a development at the coastal town of Toora (in Victoria's Gippsland region) because of the impact of climate change. It cited 'potential sea level rises due to the effects of climate change' as the basis for its decision. Similarly, in Gippsland Coastal Board v South Gippsland Shire Council [2008] (VCAT 1545), development consent for six residences along the coast was overturned by the Victorian Civil and Administrative Tribunal on climate change grounds (Bartley 2009).

The New South Wales Court of Appeal (Court of Appeal) in Minister for Planning $v$ Walker (2008) 161 LGERA 423; [2008] NSWCA 224 acknowledged that if decision makers do not adequately account for long-term environmental risk factors, including climate change, there is the potential for future challenges to planning and development approvals under the Environmental Planning and Assessment Act 1979 (NSW) (EP\&A Act). In South Australia, the Supreme Court, in Northcape Properties Pty Ltd v District Council of Yorke Peninsula [2008] SASC 57, upheld the decision by the Environment, Resources and Development Court to refuse a subdivision of a large parcel of coastal land on the basis that sea level rises and associated flood patterns caused by global warming would cause erosion to a buffer zone (Briggs and Taberner 2010). Finally, in Queensland, the Planning and Environment Court dismissed an appeal against decisions taken by Redland Shire Council to construct a building pad on the basis that it was 
relocated to an area less prone to tidal inundation (Charles \& Howard Pty Ltd $v$ Redland Shire Council [2007] QPEC 95). ${ }^{2}$

\section{Case study: Tasmania and Climate Change}

The Tasmanian case study documented the risks caused by climate change identified by local governments in the northern region of Tasmania. Results from initial desk-survey work found that a wide spectrum of environmental, social, health and economic impacts were pertinent to local government (Figure 1).

Figure 1: Estimated impacts of climate change to Tasmania

\section{Extreme Events}

- Tasmania is likely to experience moderate rises in temperatures with evaporation likely to increase in all areas except the west coast and associated highlands where small decreases are indicated.

- Rainfall is likely to increase by 7 to 11 per cent in the west and central areas, and decrease by around 8 per cent in the north-east by 2040.

- Sea level rises and frequent and severe storm surges are likely to result in inundation and erosion to Tasmania's coast.

- Warmer temperatures and changing rainfall patterns would impact on water availability.

Industry losses: Agriculture

- Tasmania's primary industries are under threat by climate change; however some industries, such as wine growing, could benefit from the projected changes in climate.

- Climate change impacts will likely lead to a decline relative to what would otherwise have been in Tasmanian farm output. Dairy output is projected to decrease by around 8 per cent by 2030 and by 12.5 per cent by 2050 .

\section{Aquaculture}

- Increased sea surface temperatures may present challenges for the production of cool-water farmed aquaculture species, such as Atlantic salmon. The value of Tasmanian salmon aquaculture was $\$ 221$ million in 2005-06. However, there is potential for adaptation by the industry.

Infrastructure

- Increases in extreme storm events are expected to cause more flash flooding, affecting industry and infrastructure, including water, sewerage and stormwater, transport and communications, and may challenge emergency services. In low-lying coastal areas infrastructure is vulnerable to sea level rise and inundation.

\footnotetext{
${ }^{2}$ A building pad exists on properties subject to flooding. It raises the natural ground level to around 300mm above Q50 (the flow of a river which is exceeded on average for $50 \%$ of the time) so that the house built on the pad with a minimum $150 \mathrm{~mm}$ slab will be the required $450 \mathrm{~mm}$ above the Q50

<www.ccbuildingapproval.com.au/Building\%20Glossary.doc>
} 


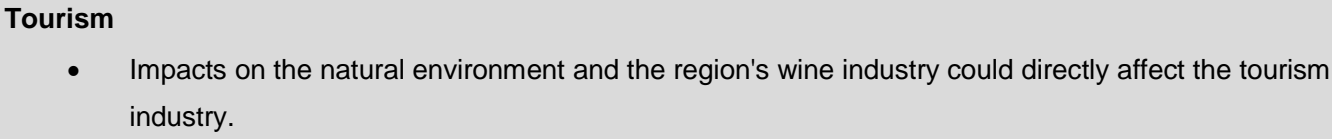

- Impacts on the natural environment and the region's wine industry could directly affect the tourism industry.

\section{Biodiversity}

- Natural habitats, especially alpine environments and coastal systems, are likely to be impacted. The Southwest region of Tasmania is densely forested and holds some of the last temperate rainforests and oldest trees in the world.

- $\quad$ The Tasmanian Wilderness World Heritage Area (TWWHA) includes most of these forests and also alpine environments. Increased temperatures from climate change will diminish the extent of Tasmania's alpine area and reduce the habitats available for native species.

- A 10-40 per cent reduction in snow cover projected by 2030 would result in a change in the dynamics of alpine communities and may lead to serious population declines of some species and loss of ecosystems.

\section{Marine Biodiversity}

- The warming of sea surface temperatures, which is projected to be greatest off south-east Australia, is likely to affect the distribution of species with flow on effects to the broader marine ecosystem. Waters off the east coast of Tasmania have recorded an increase in temperature of more than $1^{\circ} \mathrm{C}$ since the 1940 s.

- In the last decade, around 36 species of marine fish have shown noticeable changes in distribution, including range shifts further south and new species not previously recorded in Tasmania.

- The long-spined sea urchin migrated south from NSW with the southerly extension of the East Australian Current. It has spread along the east coast of Tasmania and is believed to be impacting kelp communities, with potential implications for the sustainability of rock lobster and abalone fisheries in the absence of control measures. The value of Tasmanian rock lobster and abalone production in 2004-05 was approximately $\$ 150$ million.

\section{Coastal zones}

- Over 20 per cent of the Tasmanian coastline will be a risk from sea level rise and more severe storm surges associated with climate change.

- Within in the next 50-100 years, 21 per cent of Tasmania's coast is at risk of erosion and recession from sea-level rise, potentially affecting 17,000 coastal buildings. (Based on information from the Hydro Tasmania (2006), State of Tasmania (2006), DPIWE (2004) and CSIRO Reports (2002).

The brief for the case study project was to also conduct workshops in each municipal coastal council in the Natural Resource Management (NRM) North Region of Tasmania. Workshops were designed to document the risks local governments in the northern region of Tasmania identified in relation to climate change, and inform the councils on current projects and tools in the climate change field. Project outcomes documented each council's priorities, the perceived risks that climate change presented to them, and a gap 
analysis on what other tools are needed to help councils deal with climate change impacts on their natural and man-made assets.

Eight councils were involved in the study: Georgetown Council, West Tamar, Launceston, Northern Midlands, Dorset, Flinders Island, Break O’ Day, and Meander Valley. In each case, the NRM Facilitator assisted in setting up workshop dates and meeting spaces, and undertook follow up work with the researcher to ensure project completion. Ongoing liaison occurred with NRM north staff. Launceston Council is the only council that chose not to participate, largely because funding had been previously secured to undertake a detailed risk assessment.

\section{Findings}

Developing adaptation-focused responses to climate change at a local government scale is challenging. The case study began with the intent of documenting the climate change risks that local governments in the northern region of Tasmania that have been so far been recognised. As the work progressed it became clear that the overwhelming need, as expressed by local government, was better access to climate change information. Without this, all councils felt they could not identify the scale and scope of the risks and as a result, communicate to rate payers and others the issues associated with climate change.

Other shared concerns across the case-study councils were how to deal with the uncertainty surrounding climate change impacts and how to incorporate climate change into day-to-day management or 'governance structures'. The next section outlines the above areas of shared concern and weaknesses in more detail.

\section{Issue 1: Institutional arrangements}

Workshops highlighted that local governments were aware of climate change as an issue but face a number of significant constraints including: the demands of 'sea changers'; climate change scepticism; a lack of funding; and, a lack of clarity about respective institutional obligations at local, State and Federal levels. The uncertainty of the actual impacts of climate change predictions inhibits the potential for institutional action or application of precautionary engineering solutions to effect change. This is consistent with other studies across Australia (Strengers 2004, Burton and Dregde 2007, AGO 2007, Gurran 2008) that identify similar barriers faced by local government. These include:

- Inappropriate policy scope 
- Inadequate or inappropriate public participation and involvement

- Lack of resources for policy making and implementation

- Information base is either inadequate or drawn from a narrow range of sources

- Lack of appropriate capacity and skills

- Lack of political and community support

- Institutional and leadership inertia

- Lack of adequate monitoring of policy implementation and policy review

- A shift in emphasis by key agencies from local to regional scale

- Unreasonable demands by funding agencies

- Lack of trust in the key decision-making agencies

- Some of the key agencies are perceived to have conflicting roles as both a regulator and a facilitator of policy making.

In the Tasmania study, these issues crystallised into an overarching practical concern about how councils can incorporate climate change management into existing day-to-day management. This question was raised time and again and it was clear from the research that until councils have the means to properly face the issue and deal with it directly, there is a preference to camouflage the problem within mainstream council business and local governance arrangements. Indeed, some respondents were of the view that climate change management should always be incorporated within existing governance structures as they felt this would ensure it was actually dealt with over time. This was due to a perception that climate change was the current 'big ticket, big funds' issue, but one that would fade over time, along with its funding and hence needed incorporating within governance regimes in more permanent and sustainable ways.

\section{Issue 2: Communicating the issue to rate payers and other stakeholders}

Effective communication between stakeholders and policy makers is important to the success of any program, and essential to forging links between local government and the community on climate change (Demerritt and Langdon 2004). This was a theme collectively articulated in all workshops by a diversity of staff, from engineers, to planners, to elected councillors about the ways in which the issue might be communicated. Some findings under this theme were:

- While coming from different directions, staff and councillors nonetheless faced a dilemma between the need to deal with the issue and the perception of it. 
- Staff particularly felt they were 'between a rock and a hard place', where any decision made could be uncomfortable or unpopular.

- In all workshops there was a high level of dissatisfaction within local government as to the style, substance and depth of information they had about climate change.

- Many participants noted they did not have the level of geographical detail about the predicted impacts for their own regions, and argued that this inhibited them from engaging fully with management of the issue.

- Community scepticism was also cited as a reason for the ambivalence about dealing with the issue, as was the fact that most staff, already overworked, indicated they did not have the time to 'get climate change under my belt as well...'.

Again, these results are consistent with experiences elsewhere. For example, a similar case study of local authorities within the UK in 2003 found that over three quarters of respondents felt they did not have access to the best information about the impacts of climate change on their areas. ${ }^{3}$ The survey also recorded high levels of stress, cynicism, and a sense of futility amongst these officials. The UK workshops also highlighted that there are a number of barriers to effectively communicating climate change at local levels, the first being the scale of the problem per se.

Getting stakeholders to forge the conceptual link between the global and local scale is difficult. A risk perception study undertaken in the US showed that while Americans perceived that climate change was a risk, they did not perceive that it was a risk to them personally (Lieserowitz 2006). The US research highlights the need to build the link between the issue and people, and the need to do so on a scale that resonates locally. Moreover, when the scale of the problem is seen as too large, it effectively creates inertia, as amply highlighted in research undertaken by the UK Tyndall Centre for Climate Change on the societal response to the film The Day after Tomorrow. ${ }^{4}$

\footnotetext{
${ }^{3}$ A survey of environmental officers in every Local Authority in England and Wales to assess the reception and response of local government to the information being provided through the UK Climate Change Program.

${ }^{4}$ Interestingly, findings highlighted that while the film raised awareness of the issue, it also increased people's sense of helplessness and reinforced the notion that there was little to be done about the problem, thus effectively enforcing inaction (Lowe 2006).
} 
As confirmed in the Tasmanian research, many staff and councillors raised the fact that communicating climate change was bedevilled by uncertainty. Will the sea level rise be 20 or $80 \mathrm{~cm}$ ? What will be the frequency of extreme weather events? How can planning decisions be made when the science itself is unclear? Thus the issue lacks immediacy for people, amplified by the disjuncture between people's experience of the 'weather' and the discourse about climate change. People cannot 'see' climate change, and additionally, reconcile it as being simply an 'unusual weather pattern'. Convincing them that climate change is real and that something really needs to be done about it is that much harder. ${ }^{5}$

The complicated nature of scientific and management 'speak' about climate change makes it very hard for people to understand the problem in the first place. It becomes challenging for policy makers to respond to the issue when having to interpret a multitude of documents across different disciplines. Staff at the workshops asked how they could make climate change language accessible to the general public. It was observed that:

- This is a key governance issue because unless rate payers of the local government community understand what is meant by climate change terminology, the uptake of climate change action(s) will not only be impeded, but may lead to instances of mal-adaptation.

- Access to climate change information is often constrained - too often there is a lack of knowledgeable, credible and local people who could champion effective communication about climate change.

- There is also a lack of presented alternatives, which increases the levels of disenfranchisement that individuals and communities may feel.

In Tasmania these communication issues are further hampered by the pressure caused by the migration of individuals to coastal regions popularly known as 'sea changers' (Burnley and Murphy 2004). While retirees were the original drivers of the sea change phenomenon (Gurran et al. 2008), new residents within high growth coastal areas are generally of a younger age (in some cases significantly so) than the existing profile of

\footnotetext{
5 There are a number of studies that focus on the importance of effective communication in dealing with uncertainty (Moss 2007, Lorenzoni et al. 2007, Marx et al. 2007, Patt 2007). Marx et al. (2007) argue that people process 'uncertainty information' in different ways, particularly in relation to 'hard' scientific information. They conclude that 'retranslation of statistical information into concrete experience will facilitate intuitive understanding of probabilistic information and motivate contingency plans' (Marx et al. 2007). Moss (2007) agrees with this theme noting that in order to improve decision making about climate change, scientists must improve how they communicate uncertainty to the public and decision makers.
} 
communities affected by sea change. ${ }^{6}$ While it is the baby-boomer generation who will start retiring within the decade - thus increasing the number of retirees moving to the coast - 'sea-changers' are now individuals and families of all ages. How to communicate climate change to these different stakeholders in a way that is cost effective and has impact was another issue raised at all workshops.

\section{Issue 3: Uncertainty}

Uncertainty is a key difficulty for policy makers in assessing how to deal with pinpointing how climate change will manifest, and the extent, diversity, regularity, distribution and magnitude of its impacts (Ha-Duong et al. 2007, Petit 2005). Uncertainty is a key theme in the discourse about climate change, and debate continues on how fast change will occur, at what scale, how catastrophic it will be, and on the accuracy of climate predictions (Carter et al. 1999). Uncertainty arises from insufficient, inaccurate or unavailable data, external developments and cross-boundary issues, and the unpredictability of human behaviour (Westmacott 2001). As Jones (2001) notes on the importance of uncertainty within policy planning:

\section{Uncertainty management is the raison d'etre of risk assessment, extreme care must be exercised throughout an assessment, so that uncertainties are identified, the nature of their propagation throughout the assessment is understood and that they are communicated as part of the results.' (Jones, 2001)}

In this context, there are a number of practitioners trying to address and find ways of developing planning frameworks that address uncertainty. For example, Fankhauser et al. (1999) suggests that the solution to dealing with uncertainty lies in ensuring that adaptation policy is robust, and anticipates future impacts based on a wide array of predictions. By building social and economic capacity to respond to diverse sets of circumstances, it is possible to factor in uncertainty within planning frameworks (Fankhauser \& Tol 1997). Dessai and Hulme (2007) design an assessment framework that identifies robust adaptation strategies. Using a sensitivity analysis to a case study of water resource planning in the east of England, they find that water resources are sensitive to uncertainties in regional climate response and impacts.

During the workshops, local government staff frequently talked about the difficulty of getting ahead with climate change science and how to develop strategies to assess or address uncertainty. There are a number of governance questions for local government to consider:

\footnotetext{
${ }^{6}$ The National Sea Change Task Force Report states that $79 \%$ of new residents in coastal areas are younger than 50, compared with $71 \%$ of Australia overall.
} 
- How much climate change uncertainty do we want to adapt to?

- How can we trade-off robustness with increasing cost?

- Are robust adaptation options socially, environmentally and economically acceptable?

- How do climate change uncertainties compare with other uncertainties (e.g. changes in demand for housing or natural resources)?

- How much public money should be invested to research the largest scientific (tractable) uncertainty to try to reduce it? (Dessai and Hulme 2007).

The Tasmanian case study highlights some of the problems facing local governments in their governance of climate change, including how to deal with the uncertainty of climate change predictions, how to communicate with rate payers, and how to build appropriate and resources institutional arrangements.

\section{Discussion: Implications for Governance}

This paper started with an overview of the pressures faced by some Tasmanian local governments in instituting climate change adaptation measures. The case study further highlights that there is a time lag between identification of the problem in the public arena, and the ability of professionals to respond to it. These results have some key implications on governance. Climate change is indubitably a difficult or 'wicked' problem. As Crowley (2008) observes in relation to the development of mitigation strategies, part of the way forward requires addressing local level governance structures. Indeed she describes good governance as 'well considered, well embedded, effective policy, made in the absence of pressure by special interests or electoral cycles' (Crowley 2008). I suggest that governance arrangements at local government levels incorporate and emphasise three dimensions that might underpin a 'local adaptive climate change governance framework': (i) adaptive management, (ii) communications and (iii) reflexive practice into local governance structures. These are outlined in further detail.

\section{Building Local Adaptive Climate Change Governance - A Framework}

\section{Dimension 1: Adaptive Management}

Incorporating 'adaptive management' principles into governance is one way of building 'key stones' for governance at local and domestic policy levels. Adaptive management is based on the assumption that circumstances change (Leach 2006). It is a technique that 
provides a framework for continually improving managerial practices. Adaptive management can also build on environmental assessment techniques to deal with uncertainty, making it ideal for climate change management (Holling 1986). Thus, adaptive management can embed greater fluidity and flexibility within conventional environmental management systems, one that is based on the principle of continuous improvement. The fluid nature of adaptive management also suits the dynamics of working with the changing quality of coastal areas - of great interest to a majority of Australian local governments.

Implementing adaptive management takes place in two phases: (i) the institutionalisation of a framework in which intentional and varied policies may be implemented, and (ii) learning over time by monitoring the responses of the system on which the varied experimental policy systems have been implemented (Arvai et al. 2006). Employing adaptive management techniques can enable policy makers to focus on variation over time within policy, and local government planners could deal with this by reviewing their planning schemes periodically. Another strategy could be to 'mainstream' climate change into existing strategies and day-to-day business, otherwise known as 'climate proofing'. As such, adaptive management enables the synchronous treatment of different options across periods of time and place.

Moreover, local governments would benefit from building more strategic alliances with their rate payers and other local/community groups to build greater acceptance of, and willingness to trial different mitigation and adaptation options. ${ }^{7}$ As part of a local governance framework, an adaptive management dimension could guide planners at the evaluation stage of coastal management programs. Such a framework could have five elements: (i) information collation, (ii) systems analysis and vision, (iii) plan making, (iv) implementing actions, and (v) monitoring and reviewing (adapted from Leach 2006). Embedding adaptive management then as a key feature of local governance will in turn encourage development of good climate policy.

\section{Dimension 2: Communications}

International experience shows that there are a number of ways in which climate change can be communicated effectively (Moser 2005). A local climate change governance

\footnotetext{
7 The idea of trial and error is an overlooked one, but one that is supported within the idea of continuous improvement embodied within adaptive management.
} 
framework needs to have a communications component so the need both to develop and then implement climate change management can be accepted. Within this there are two key principles:

1. Local governments need to be transparent about communicating the issue by: communicating the existence of increasing climate change and variability using the science to explain current climate events and possible future ramifications, communicating the need to take proactive action to ameliorate negative impacts, and create the conditions for discussing positive adaptation strategies and shared experiences and lessons.

2. Employing other strategies to ensure communication about climate change is appropriate, by: choosing language that is appropriate to the audience (a good first step); concentrating on what is feasible for different groups (important); and maximising opportunities by aligning climate change as an issue with other contemporary issues that resonate with local interests and local agendas (NurseyBray and Ferrier 2009).

What does this mean for local governments that have, or are already developing responses to climate change? A number of suggestions are made:

1. Communicating the idea of climate change management so it is culturally palatable.

Communication materials and strategies need to work within the culturally accepted discourse at local government level about how this issue is run and implemented. These may need to be varied depending on whether the audience is ratepayers, internal staff or elected councillors. Important but often overlooked is the requirement to employ, or get advice from, communications professionals on how to do this - good content or knowledge is sometimes not enough to translate and convey information so it can be understood and accepted. Ultimately, communication strategies must also be based on solid guidelines. ${ }^{8}$

\footnotetext{
${ }^{8}$ While these principles are commonly understood by communication practitioners, they bear repeating: (i) carefully define communication goals, (ii) identify and characterize the intended audiences, (iii) have those working on the front lines well informed and committed, (iv) ensure that communication is not just one-way and (v) don't reinvent the wheel; learn from other fields and from retrospective/evaluative studies of climate change communication efforts. There are many resources on communication and climate change that might be adapted. See for instance the centre for the Communication of Climate Change, based at Mason University: <http://www.climatechangecommunication.org/>. Another good source is the proceedings of a conference on communicating climate change, a 657 page document that can be downloaded and/or viewed at $<$ http://dsp-psd.pwgsc.gc.ca/Collection/En56-157-2000E.pdf $>$
} 


\section{Consistent communications}

Building communication strategies that are in line with existing branding and messages about the place or locale makes good sense. For example, Tasmania is branded as 'clean and green', a message that its local governments could use to build their profiles and to market climate change projects and schemes. This would be especially persuasive to many 'sea changers' and would reflect back to this demographic some of their original motivations in moving to Tasmania.

\section{All interests need to be involved}

Involving all groups (from the smallest Landcare group to the Mayor) will not only build trust in the project, but will build momentum as the network of each party becomes employed. This creates a ripple effect and maximises the effectiveness of the message.

The role of and power of social networks could be better harnessed or considered in this space as could the role of interdisciplinary collaboration (Nursey-Bray 2008, 2009).

\section{4. 'Mainstreaming' climate change into existing processes}

Most local governments already have strong emergency management or occupational health and safety departments therefore, adding climate change into existing processes is a very useful mechanism. For example, climate change could be incorporated into policies regarding flood management without too much difficulty. In such ways, climate change management and impacts can be subtly communicated and disseminated through the community.

\section{Dimension 3: Reflexive practice}

This concerns putting practice into policy and embedding reflective practice as a guiding principle within climate change for local level governance. There is an enormous amount of work currently underway in Australia and internationally on the topic (see figure 2 for a snapshot). This scope is a reminder that local governments do not have to reinvent the wheel but build upon what has already been done.

\section{Figure 2: Review of climate change programs in local government}

\section{International}

- Cities for Climate Protection: International program launched in Australia 1997 that encourages councils to reduce greenhouse gases and undertake other climate change management activities.

- $\quad 40$ Cities Project: The 40 Cities project gives advice and real case study examples of how local governments across the world are navigating successful adaptation to change and achievements in environmental sustainability in the areas of housing, energy, renewals, ports, transport, water, waste etc (see http://www.c40cities.org/bestpractices). 
- The Beacon Scheme: UK schemes designed to develop and share best practice in service delivery across local government.

- $\quad$ City of London Adaptation Strategy: The City of London has developed Rising to the Challenge The City of London Corporation's Climate Adaptation Strategy 2007.

- $\quad$ East Riding of Yorkshire Council Coastline 'Rollback': East Riding of Yorkshire Council is implementing a coastal 'rollback' strategy to manage high rates of coastal erosion as part of its Integrated Coastal Zone Management Plan.

- City of Keene Climate Adaptation Plan: US based city Keene, developed Adapting to Climate Change: Planning a Climate Resilient Community.

- 2007 King County Climate Plan: US based, in King County, Washington, has a climate plan that incorporates climate change mitigation and adaptation into agency activities, plans, policies and major investments.

- California Climate Change adaptation plan: Has developed comprehensive Climate Change Adaptation Plan, with a detailed action plan, with timelines for each objective.

National

- The Local Government and Planning Ministers' Council (LGPMC): One of 40 Commonwealth-State Ministerial Councils that in 2009 agreed to develop national framework and tools for local government to help them in planning for climate change.

- Australian Local Government Association: Runs many climate change initiatives, and is base for information about how to conduct climate change actions.

State based local government associations

- Local Government Response, South Australia: Some initiatives include the (i) LGA Climate Change Strategy 2008-2012, (ii) Climate Change Sector Agreement with the SA Government, (iii) Climate Change Risk Management and Adaptation Program, (iv) Beyond Carbon - Local Government Climate Change Summit, (v) provision of Information Papers, (vi) a Climate Change Questionnaire Survey, and (vii) the LGA Climate Change Strategy 2008-2012. ${ }^{9}$

- Victorian Local Government and Climate Change: Provides information on how to undertake climate change actions with examples - Victoria Local Government and Climate Change: Case Studies. ${ }^{10}$

- NSW Local Government association: Amongst other support and initiatives exists a Climate Change Action Pack - An online resource for NSW Local Government on the NSW LGA web site. This action pack includes information on Tools, templates and techniques for addressing climate change, case studies, news, media releases, upcoming events and funding opportunities, and links to other useful websites (see http://www.lgsa.org.au/www/html/1899-climate-change.asp).

- Western Australia Local Government Association: WALGA has developed a detailed web site / toolkit that provides needed information to councils in relation to climate change management. ${ }^{11}$

- Municipal Association of Victoria: The Local Government Climate Change Mitigation and Adaptation program has been operating for four years to help councils address the significant challenge that climate change presents.

- Local Government Association of Tasmania: Also has a good climate change toolkit and a suite of suggestions for local government on how to deal with this issue. ${ }^{12}$

${ }_{10}^{9}$ For more information on these projects see $<\underline{\text { http://www.lga.sa.gov.au }}>$

10 See:

$<$ http://www.climatechange.vic.gov.au/summit/Resources/Vic+Local+Gov+Climate+Change+Case+Studies \%5B1\%5D.pdf $>$

${ }^{11}$ See $<$ http://www.walgaclimatechange.com.au/planning-case-studies.htm> 


\section{Regional initiatives}

- The Western Port Greenhouse Alliance: The WPGA carries out projects to help councils and the community respond to climate change.

- Sydney Coastal Councils: The SCCG has, with CSIRO's Climate Change Adaptation Flagship and University of the Sunshine Coast, developed a Systems Approach to Regional Climate Change Adaptation Strategies in Metropolises. The aim is to work with the 15 SCCG Member Councils to determine key vulnerabilities and their capacity to adapt to manage climate change issues at a regional scale.

Some examples of local initiatives

- Climate Change and Coastal Risk Assessment Project, Tasmania: The project takes a risk management approach to produce a range of tools to assist with the development and implementation of adaptation and mitigation strategies. It will identify the probabilities relating to various sea-level rise scenarios that will need to become a foundation of future risk assessments in the coastal zone.

- Clarence Council Foreshores Project: Integrated Assessment and Response to Climate Change Impacts on Clarence Foreshores (CCC). This project has determined what climate change impacts will be and what to do about them in the Clarence Foreshores.

- Kingborough Council Risk Assessment for Climate Change Decision Making Tool: Kingborough has conducted and built a risk assessment tool to enable staff to assess risks in relation to climate change impacts (Nursey-Bray and Ferrier 2009). The risk assessment tool is based on a $800 \mathrm{~mm}$ rise over 100 years.

- West Tamar Council: The West Tamar Planning Scheme (2007) has formal sections addressing climate change that mean that all building location and design must ensure that (a) it will not cumulatively increase the risk of flood to other land, and (b) takes into account potential sea level rise due to global warming.

\section{Other examples}

- Peel Harvey Climate Change Adaptation Project; Ku-ring-gai Council Risk Assessment and Cost Benefit Model; Western Port Human Settlements Impacts and Adaptation Project; Hunter and Central Coast Regional Environmental Management Strategy Climate Change Adaptation Project; Ku-ring-gai Council Water Conservation Projects; Port Adelaide-Enfield Council Flood Risk Study; Byron Shire Council Climate Change Planning; Manly Council Ocean Beach Coastline Management Plan.

What is a challenge for local government professionals is finding the time to invest in a review of other initiatives and practices and how then to adapt them to suit individual needs or locales. For example, local governance reform could be as simple as appointing someone within Council with the responsibility of (a) developing a data base of information relevant to the municipality, (b) updating it in relation to the current science, and (c) communicating key ideas. Another option is to dedicate a web link within the Council web site to this action. Councils could also collate a database of experts in the region and invite these experts to give regular briefings within Council sessions over the

12 See $<$ http://www.lgat.tas.gov.au/site/page.cfm?u=542> 
yearly cycle. Councils also may pursue funds to enable specific scientific work and social / economic assessment in their region.

This form of reflexive practice as part of a local governance framework for climate change will also cut costs, and facilitate innovation on existing ideas. Introducing policy makers to existing initiatives in this manner also lessens the pressure caused by the sheer psychological weight of climate change, and can help organisations build regional to international alliances and networks that may offer future opportunities to adapt to change.

\section{Conclusions}

This study highlights that at time of writing, with a few exceptions, the case-study councils were only just beginning the conversation about climate change and climate change management. Thus the project, while not fulfilling its anticipated objective, revealed some core vulnerabilities within local governance arrangements about climate change. Local governments face increasing challenges in developing responses to climate change and need to work on both mitigation and adaptation strategies. Effective governance regimes (that operate at domestic policy levels) will be the cornerstone of the successful implementation of climate change programs.

Using the results of a Tasmanian case study, this paper has presented a model of adaptive climate change governance based on the three dimensions of adaptive governance, communication and reflexive practice. I argue that for local governments to enact good governance, these elements need to be built into domestic policy detail. Also highlighted is the opportunity inherent in looking to and working with other projects and initiatives, saving both time and costs. In Tasmania, local governments need to consider how (both separately and together) they can continue this conversation, and build programs and locally responsive governance arrangements which will insure councils against, and assist them to adapt to, the impacts of climate change in the future. Climate change is more than making locally specific information about climate change impacts available. Motivation and appropriate action on the ground will only occur when confidence is built up at local level.

\section{References}

Arvai, J., Bridge, G., Dolsak, N., Franzese, R., Koontz, T., Luginbuhl, A., Robbins, P., Richards, K., Korfmacher, K., Sohngen, B., Tansey, J., and A. Thompson. (2006) 'Adaptive 
Management of Global Climate Problem: Bridging the Gap between climate research and climate policy', Climatic Change, 78, pp. $217-225$

Australian Greenhouse Office (2007) Climate Change Adaptation Actions for Local Government, Australian Government Publishing Service.

Bartley, M (2009) Coastal developments and climate change impacts - recent policy and case law, DLA Phillips Fox

Briggs, P and Taberner, J (2010) Climate change litigation to flood planning and development in coastal areas . at http://www.freehills.com.au/5789.aspx , viewed December 122010.

Burnley, I. and Murphy, P. (2004) Sea change : movement from metropolitan to arcadian Australia, UNSW press, Sydney

Burton, D. and Dredge, D. (2007) Framing Climate: Implications for Local Government Policy Response Capacity, Griffith University, accessed on 7 December, $2010<$ http://www.griffith.edu.au/_data/assets/file/0004/29821/burton-dredge-implicationslocalgovernment.pdf

Carter, T., Hulme, M., and Viner, D. (Eds.) (1999) 'Representing uncertainty in climate change scenarios and impact studies,' Proceedings of the ECLAT-2 Helsinki Workshop, 14-16 April 1999, Climatic Research Unit, Norwich, UK, 128pp

CSIRO (2002) Climate Change and Coastal Communities, CSIRO, Victoria, Australia.

Crowley, K (2009) 'The devil is in the detail: The Governance Challenge of Climate Change', refereed paper presented to the National Public Policy Network Conference 2009 Research School of Social Sciences, ANU 29-30 January 2009

Demeritt, D. and Langdon, D. ( 2004) 'The UK Climate Change Programme and Communication with Local Authorities, Global Environmental Change, 14, pp 325 - 336

Dessai, S, and Hulme, M. (2007). 'Assessing the robustness of adaptation decisions to climate change uncertainties: a case-study on water resources management in the East of England', Global Environmental Change 17 (1)

DPIWE. (2004). Sea level Change Around Tasmania, Hobart

Edgar, A. (2010) 'Participation and Responsiveness in Merits Review of Polycentric Decisions: A Comparison of Development Assessment Appeals (July 28, 2010)’. Environmental and Planning Law Journal, Vol. 27, No. 1, pp. 36-52, 2010; Sydney Law School Research Paper No. 10/68.

England, P. (2006) Climate Change: What Are Local Governments Liable for? Urban Research Program Issues Paper 6, Griffith University

Fankhauser, S. and Tol, R. (1997) 'The social costs of climate change: the IPCC second assessment report and beyond', Mitigation and Adaptation Strategies for Global Change, 1, pp. 385-403

Fankhauser, S., Smith, J., and Tol, R. (1999) 'Weathering climate change: some simple rules to guide adaptation decisions’, Ecological Economics, 30(1), pp. 67-78

Gurran, N., Hamin., E., and Norman, B. (2008) Planning for climate change: Leading Practice Principles and Models for Sea Change Communities in Coastal Australia, National Sea Change Task Force

Ha-Duong, M., Swart, R, Bernstein, L., Petersen, A., (2007) 'Uncertainty management in the IPCC: agreeing to disagree’, Global Environmental Change 17 (1)

Holling, CS. (1986) 'Resilience of ecosystems: local surprise and global change’, Clark, WC, Munn, RE. (Eds.), Sustainable Development and the Biosphere, Cambridge University Press, Cambridge

Hydro Tasmania. (2006) Tasmanian Climate Change: Fact Sheet - April 2006. A Hydro Tasmania, CSIRO, UTAS and TPAC Project, Published by Hydro Tasmania 
Intergovernmental Panel on Climate Change (IPCC). (2007) Climate Change 2001: Impacts, Adaptation Vulnerability. Contribution of Working Group II to the Third Assessment Report of the Intergovernmental Panel on Climate Change. Geneva: UNEP/WMO

Jones, R. (2001). 'An Environmental Risk Assessment/Management Framework for Climate Change Impacts Assessments’, Natural Hazards, 23, pp. 197 - 230

Leach, G. (2006) Enabling Adaptive Management for Regional Natural Resource Management, CRC Coastal Zone Estuary and Waterway Management

Leiserowitz, A. (2006). 'Climate Change Risk Perception and Policy Preferences: The role of Affect, Imagery and Values’, Climatic Change (2006) 77, pp. 45-72

Lorenzoni, I., Jordan, A., Hulme, M., Turner, K., and O’Riordan, T. (2000) ‘A Co-Evolutionary Approach to Climate Change Impact Assessment,' Global Environmental Change 10, pp. $57-68$.

Lowe, T. (2006) 'Does tomorrow ever come? Disaster narratives ad public perceptions of climate change’, Public Understanding of Science, 15: 435 - 457.

Marx, S., Weber, E.U., Orove, B.S., Leiserowitz, A., Krantz, D.H., Roncoli, C., Phillips, J., (2007) 'Communication and mental processes: experiential and analytic processing of uncertain climate information’, Global Environmental Change 17 (1).

Moser, S. (2005) 'Impact assessments and policy responses to sea-level rise in three US states: An exploration of human-dimension uncertainties’, Global Environmental Change, 15, (4) pp. 353-369.

Moss, RH. (2007). 'Improving information for managing and uncertain future climate', Global Environmental Change, 17 (1).

Nursey-Bray, M. (2008) 'Inter-disciplinarity as a tool for action on climate change: Applying social science methodology to climate change initiatives within local government, Australia', in The International Journal of Inter-disciplinary Social Sciences, Vol 2, pp112.

Nursey-Bray, M. (2009) 'Climate Change, Coastal Communities and Governance: Developing solutions for change, Australia ', in Dahl, E, Moksness, E and Stottrup, J (Eds) Integrated Coastal Zone Management, Wiley-Blackwells press, Australia.

Nursey-Bray, M. and Ferrier, T. (2009) Risk assessment and local government, Tasmania: Applying an inter-disciplinary approach to climate change adaptation, for book Eds Mannke, Franziska Inter-disciplinary Aspects of Climate Change, Peter Lang Scientific Publishers.

Patt, A. (2007) ‘Assessing model-based and conflict-based uncertainty’, Global Environmental Change, 17 (1), pp. 37 - 46.

Petit, M. (2005). 'Scientific uncertainties and climate risks', Comptes Rendus Geoscience 337, pp.393-398.

Pillora, S. (2010) Australian local government and Climate Change, Australian Centre of Excellence for Local Government.

State of Tasmania. (2006) State of Environment Report, Recommendation 7.6: Adapting Coastal Settlements to Climate Change <http://www.rpdc.tas.gov.au/soer/index/contents.php>

Strengers, Y. (2004) Environmental culture change in local government: a practiced perspective from the International Council for Local Environmental InitiativesAustralia/New Zealand, Local Environment, 9(6), pp. 621-628.

Westmacott, S. (2001) 'Developing Decision Support Systems for Integrated Coastal Management in the Tropics: Is the ICM Decision-Making Environment Too Complex for the Development of a Useable and Useful DSS?' Journal of Environmental Management, 62(1), pp. 55-74. 